\title{
Long-term follow-up after aortic valve replacement with Edwards Prima Plus stentless bioprostheses in patients younger than 60 years of age
}

\author{
Torsten Christ, MD, Herko Grubitzsch, MD, PhD, Benjamin Claus, MD, and Wolfgang Konertz, MD, PhD
}

\begin{abstract}
Objectives: The Edwards Prima Plus was one of the first stentless aortic valve bioprostheses, with larger orifice areas and improved hemodynamics compared to stented bioprostheses. The aim of the present single-center retrospective study was to assess the long-term results of the Edwards Prima Plus in patients 60 years old or younger.

Methods: From 1993 to 2001, 120 patients (99 men and 21 women) aged 60 years or younger underwent implantation of the Edwards Prima Plus. The indications were stenosis and/or insufficiency. Associated procedures were performed in 38 patients $(31.7 \%)$. Of the patients, $39 \%$ had impaired left ventricular function. Follow-up data were acquired by telephone interview. Time-to event analyses were performed using the Kaplan-Meier method. Variables affecting survival and freedom from reoperation were evaluated using Cox regression analysis. The mean patient age at surgery was $53.1 \pm 8.0$ years. The follow-up data were $88.8 \% \mathrm{com}$ plete at a mean of $8.5 \pm 4.5$ years. The total follow-up was 1022.7 patient-years.
\end{abstract}

Results: At 10 and 15 years, the overall actuarial survival rate was $71.8 \% \pm 4.4 \%$ and $48.8 \% \pm 9.6 \%$, respectively. Survival was significantly lower for patients with older age, aortic insufficiency as the surgical indication, and small prosthesis size ( $\leq 25 \mathrm{~mm}$ vs $\geq 27 \mathrm{~mm}$ ). Reoperation was performed in 20 patients $(16.7 \%$ ), with a hospital mortality of $5 \%$. At 10 and 14 years, the overall freedom from reoperation rate was $85.6 \% \pm 3.7 \%$ and $65.2 \% \pm 8.6 \%$, respectively. Freedom from reoperation was significantly lower in patients with a small prosthesis size $(\leq 25 \mathrm{~mm})$ and insufficiency as the indication for surgery.

Conclusions: In patients aged 60 years or younger, an Edwards Prima Plus can provide reliable long-term results with acceptable freedom-from-reoperation rates. (J Thorac Cardiovasc Surg 2014;147:264-9)

The Edwards Prima Plus (EPP) was introduced in the early 1990s. It is one of the first stentless aortic valves (SAVs). The SAVs have larger orifice areas and lower transvalvular pressure gradients than the stented aortic valve replacements (AVRs) owing to improved hemodynamics. ${ }^{1}$ Reduced calcification in the murine model could be shown for the preservation method used for the EPP. ${ }^{2}$ Furthermore, the clinical midterm results also revealed excellent freedom from structural valve deterioration. ${ }^{3}$

The actual guidelines recommend mechanical AVR in patients aged 60 years or younger and bioprosthetic AVR in patients older than 60 years. ${ }^{4}$ This is because of the greater durability of mechanical AVR, which circumvents the need for later reoperations. However, no significant difference exists in survival between mechanical and bioprosthetic AVR. ${ }^{5}$ EPP could have better longevity and therefore also be used in younger patients, because it has

$\overline{\text { From the Clinic }}$ for Cardiovascular Surgery, Charité-Universitätsmedizin Berlin, Berlin, Germany.

Disclosures: Authors have nothing to disclose with regard to commercial support. Received for publication Aug 8, 2012; revisions received Sept 25, 2012; accepted for publication Oct 22, 2012; available ahead of print Nov 16, 2012.

Address for reprints: Torsten Christ, MD, Clinic for Cardiovascular Surgery, Charité-Universitätsmedizin Berlin, Charitéplatz 1, Berlin 10117, Germany

(E-mail: torsten.christ@charite.de).

$0022-5223 / \$ 36.00$

Copyright (c) 2014 by The American Association for Thoracic Surgery

http://dx.doi.org/10.1016/j.jtcvs.2012.10.032 demonstrated advanced hemodynamics and a reduced potential for calcification. The aim of the present singlecenter retrospective study was to assess the long-term results after implantation of an EPP in patients aged 60 years or younger to determine whether the age recommendation in guidelines can be lowered for implantation of EPPs.

\section{METHODS}

From 1993 to 2001, 120 consecutive patients aged 60 years or younger underwent implantation of an EPP. Either the patient's explicit desire for a bioprosthetic AVR or a contraindication to oral anticoagulation resulted in the choice of an EPP. During the study period, 321 patients aged 60 years or younger underwent implantation of a mechanical prosthesis in the aortic position. The indications were stenosis and/or regurgitation. $\mathrm{Pa}$ tients with endocarditis and dissections of the ascending aorta were excluded.

Follow-up data were acquired through telephone interviews and/or clinical examination and follow-up was closed on October 21, 2010. The follow-up data were $88.8 \%$ complete at a mean of $8.5 \pm 4.5$ years. The total follow-up period was 1022.7 patient-years, with a maximum of 17.0 years.

Data collection and statistical analyses were done according to the current guidelines for reporting mortality and morbidity after cardiac valve interventions. ${ }^{6}$ The local ethics committee approved the study.

\section{Statistical Analysis}

All data were analyzed with PASW Statistics, version 18.0.0 (SPSS, Chicago, Ill). Descriptive statistics are reported as the mean \pm standard deviation for continuous variables and as frequencies and percentages 


\section{Abbreviations and Acronyms}

$\mathrm{AVR}=$ aortic valve replacement

$\mathrm{EPP}=$ Edwards Prima Plus

$\mathrm{SAV}=$ stentless aortic valve

for categorical variables, unless otherwise noted. Survival and time-toevent analyses were performed using Kaplan-Meier actuarial methods. Age-stratified curve comparisons were performed using the log-rank test. All $P$ values were 2 -sided. In addition, proportional hazard models were used to investigate the following variables as risk factors for survival and freedom from reoperation: gender, age, left ventricular function, aortic valve lesion, associated procedures, and EPP diameter. The preoperative characteristics often associated with mortality (eg, renal function, diabetes, chronic obstructive lung disease, peripheral arterial disease, pulmonary hypertension) were not adequately captured during the earlier portion of the study. In the later portion of the study, these characteristics were not often present (probably because of the low age of the study cohort). Thus, these characteristics were not entered as covariates in the analyses.

Age- and gender-matched survival estimates from the German general population were obtained from the Human Life Table Database. ${ }^{7}$ Ageand gender-specific conditional probabilities of surviving a 1-year age interval were used to create an age- and gender-matched patient sample. The survival line depicted in Figure 1 represents these averaged conditional probabilities of survival.

\section{RESULTS}

The baseline preoperative characteristics and operative data are presented in Table 1.

Overall, the hospital mortality was $3.3 \%(n=4)$. At 10 and 15 years, the overall actuarial survival rate was $71.8 \% \pm 4.4 \%$ and $48.8 \% \pm 9.6 \%$, respectively
(Figure 1). For isolated implantation of an EPP, the actuarial survival at 10 and 15 years was $69.5 \% \pm 5.5 \%$ and $62.5 \% \pm 8.2 \%$. The linearized mortality rate was $3.3 \% / y$ overall and 3.0\%/y for isolated implantation of an EPP. On univariate risk stratification, older age, isolated insufficiency as the surgical indication, and small prosthesis size (EPP $\leq 25 \mathrm{~mm}$ vs $\geq 27 \mathrm{~mm}$ ) significantly lowered survival. Multivariate risk stratification supported these risk factors (Table 2).

Overall, reoperation was performed in 20 patients: in 17 because of structural valve deterioration and in 3 because of endocarditis. At 10 and 14 years, the overall freedom from reoperation rate was $85.6 \% \pm 3.7 \%$ and $65.2 \% \pm 8.6 \%$, respectively (Figure 2). Only 1 patient was at risk at 15 years for determining the freedom from reoperation rate and 3 patients were for determining the 14-year freedom from reoperation rate. Therefore, the later reoperation rates should be considered with caution, and additional follow-up is needed. Univariate and multivariate risk stratification revealed small prosthesis size (EPP $\leq 25 \mathrm{~mm}$ vs $\geq 27$ $\mathrm{mm}$ ) and isolated insufficiency as the surgical indication as predictors of inferior freedom-from-reoperation rates (Table 2).

The hospital mortality of patients after reoperation was $5 \%(\mathrm{n}=1)$ and, in consideration of the low number of cases, comparable to the overall hospital mortality.

\section{DISCUSSION}

The use of biologic AVR in younger patients is still controversial. The major disadvantage of biologic AVR is structural

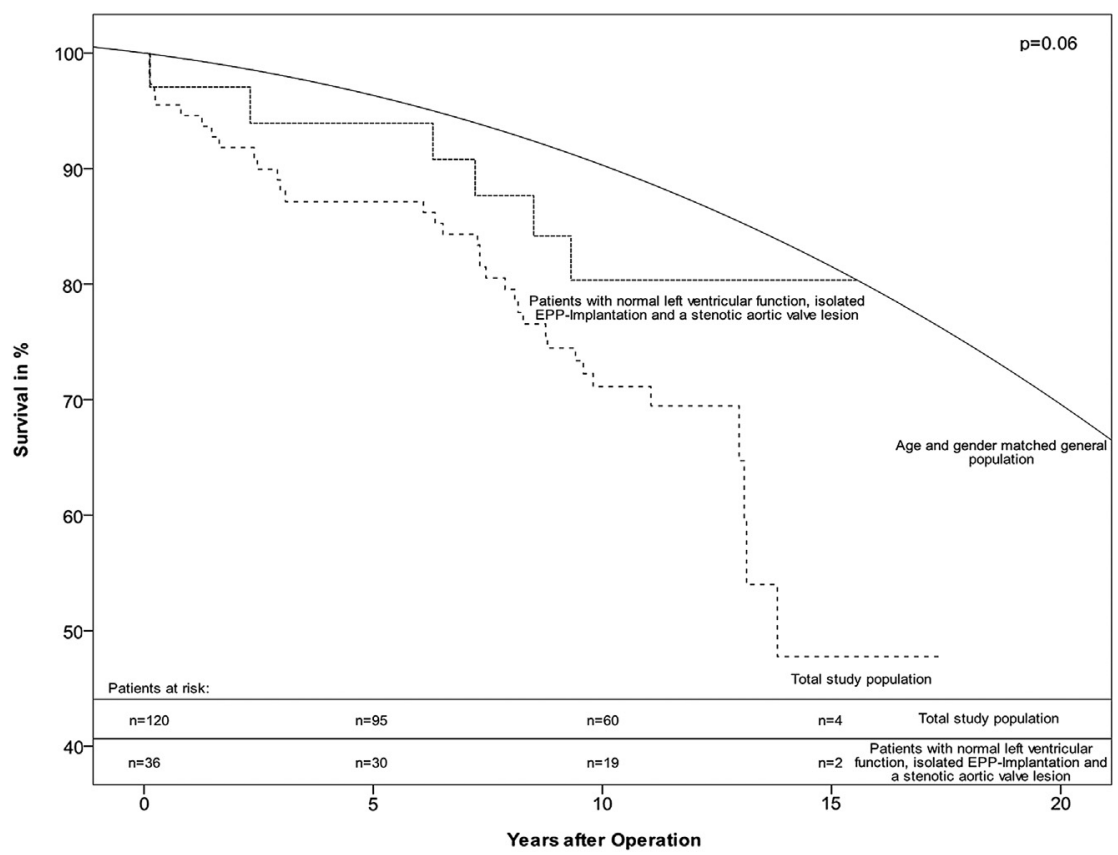

FIGURE 1. Survival of study population compared with general population and patients with normal left ventricular function, isolated aortic valve procedure, and stenotic valve lesion. EPP, Edwards Prima Plus. 
TABLE 1. Baseline characteristics and operative data

\begin{tabular}{lc}
\hline \multicolumn{1}{c}{ Characteristic } & Value \\
\hline Patients & 120 \\
Mean age (y) & $53.1 \pm 8.0$ \\
Gender & \\
$\quad$ Male & $99(82.5)$ \\
$\quad$ Female & $21(17.5)$ \\
Aortic valve lesion & \\
$\quad$ Stenosis & $38(31.7)$ \\
Insufficiency & $51(42.5)$ \\
Mixed lesion & $31(25.8)$ \\
Left ventricular function & \\
Normal (LVEF $>50 \%)$ & $73(61)$ \\
Moderately impaired (LVEF $<50 \%$ but $>30 \%)$ & $33(27)$ \\
Profoundly impaired (LVEF $<30 \%)$ & $14(12)$ \\
Isolated EPP implantation & $82(68.3)$ \\
Combined procedure & $38(31.7)$ \\
Implanted valve size (mm) & \\
23 & $1(0.8)$ \\
25 & $22(18.3)$ \\
27 & $50(41.7)$ \\
29 & $47(29.2)$ \\
\hline
\end{tabular}

Data in parentheses are percentages. $E P P$, Edwards Prima Plus; $L V E F$, left ventricular ejection fraction.

valve deterioration and the need for reoperation. In 1998 and 2006, the American Heart Association and the American College of Cardiology recommended the use of bioprosthetic AVR in patients older than 65 years. ${ }^{8,9}$ An update in 2010 lowered the age to 60 years ${ }^{4}$ because of improved valve durability and lowered risk of reoperation, even with the increasing life expectancy. The EPP, as a representative of SAVs, shows better hemodynamic performance than a stented AVR. ${ }^{1}$ In patients with left ventricular impairment, implantation of SAVs results in greater improvement of left ventricular function ${ }^{10}$ and a reduction of late mortality is shown. ${ }^{11}$ Additionally, there could be an effect on longterm durability, owing to less stress on the bioprosthetic cusps caused by a more physiologic flow pattern.

Various studies have reported on the mortality and durability after AVR, but only few were primarily concerned

TABLE 2. Risk factors for survival and freedom from reoperation in multivariate analysis

\begin{tabular}{|c|c|c|c|c|c|c|}
\hline \multirow[b]{2}{*}{ Characteristic } & \multicolumn{3}{|c|}{ Survival } & \multicolumn{3}{|c|}{$\begin{array}{c}\text { Freedom from } \\
\text { reoperation }\end{array}$} \\
\hline & OR & $95 \%$ CI & $\begin{array}{c}P \\
\text { value }\end{array}$ & OR & 95\% CI & $\begin{array}{c}P \\
\text { value } \\
\end{array}$ \\
\hline Age & 1.07 & $1.01-1.14$ & .04 & 0.96 & $0.97-0.92$ & .22 \\
\hline Gender & 1.68 & $0.56-5.04$ & .35 & 4.05 & $0.94-17.5$ & .06 \\
\hline Aortic valve lesion & 5.17 & $1.38-15.64$ & .01 & 0.25 & $0.09-0.71$ & .01 \\
\hline Left ventricular function & 0.46 & $0.17-1.21$ & .11 & 1.68 & $0.6-4.7$ & .33 \\
\hline Associated procedures & 1.44 & $0.68-3.04$ & .34 & 1.68 & $0.57-4.95$ & .34 \\
\hline $\begin{array}{l}\text { Diameter of EPP } \\
\qquad(\leq 25 \mathrm{~mm})\end{array}$ & 3.06 & $1.49-6.3$ & .00 & 6.36 & $2.26-17.87$ & .00 \\
\hline
\end{tabular}

with the long-term results in younger patients. For example, Weber and colleagues ${ }^{12}$ recently published a comparison of stented pericardial tissue valves and mechanical prostheses for AVR in patients younger than 60 years old. They reported a reduced midterm survival after implantation of stented pericardial tissue valves; however, they had a mean follow-up of just 33 months. In particular, for SAVs, owing to their introduction only about 20 years ago, only few long-term results have been published for larger cohorts of patients aged 60 years old. For example, Bach and colleagues ${ }^{13}$ reported excellent clinical outcomes and durability for the Medtronic Freestyle prosthesis (Medtronic, Minneapolis, Minn), although they reported on only about 57 patients with a mean follow-up of just 6.8 years. For the EPP, no long-term results for patients aged 60 years or younger have been published. The longest published follow-up has been for patients with a mean age of 72.2 years. ${ }^{14}$

Data for comparison of our study population was found in the younger subgroups of larger studies. In general, one should always consider the differences between the study cohorts, because of their influence on the outcome. Survival will be lowered by various comorbidities, the use of combined procedures, and an impaired left ventricular function. Furthermore, isolated insufficiency as cause of AVR is associated with inferior early- and long-term survival, especially in younger age patients. ${ }^{15}$ The age of the study cohort is of particular importance, because it influences the survival of the study cohort and the durability of the prostheses and because freedom from reoperation decreases with the younger age of patients. ${ }^{5}$ These facts must be considered, because our study cohort had a high fraction of patients with impaired left ventricular function $(39 \%)$ and isolated insufficiency as the surgical indication $(42.5 \%)$, and in $31.7 \%$ of the cases, additional procedures were done.

A review of selected studies is presented in Table 3, which clarifies the comparable survival throughout the different valve types, if one remembers the differences in the study cohorts (especially the difference in the mean age). For the comparison of bioprosthetic AVR and mechanical AVR, comparable survival was also approved by several randomized trials. ${ }^{5,16}$ However, Ruel and colleagues ${ }^{16}$ showed a survival advantage of about $13 \%$ at 20 years of follow-up for bioprostheses compared with mechanical AVR. Freedom from death, attributable to ischemic or hemorrhagic stroke after 20 years, was $14 \%$ greater for those with tissue AVR than those with mechanical AVR. ${ }^{16}$ Additionally, the requirement for lifelong anticoagulation treatment ${ }^{17}$ results in an elevated risk of bleeding ${ }^{18}$ and thromboembolic complications. ${ }^{15}$

The comparison with the age- and gender-matched general German population was done by creating a comparable cohort inside our study population. To obtain such a cohort, 


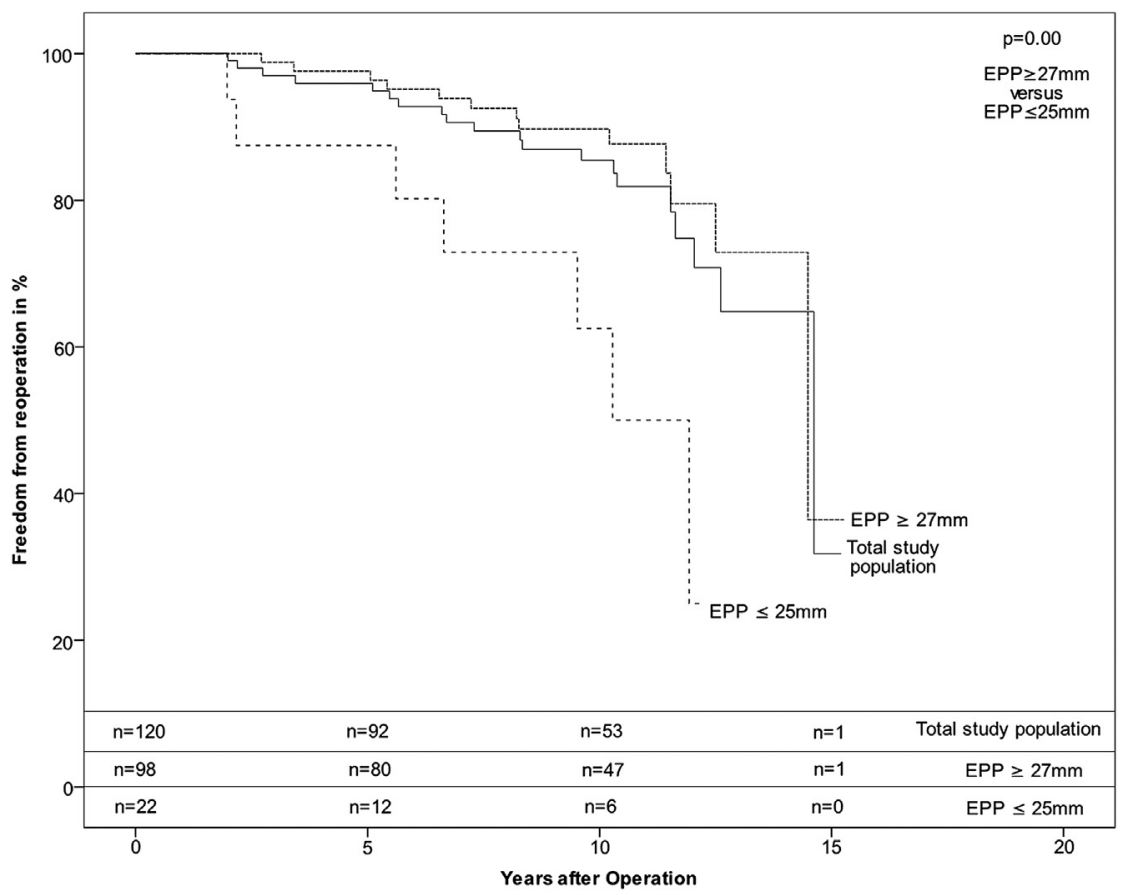

FIGURE 2. Freedom from reoperation of total study population and stratified by diameter of Edwards Prima Plus (EPP).

we included the patients with isolated implantation of an EPP and normal left ventricular function. The patients with isolated aortic valve regurgitation as the surgical indication were excluded because of the previously mentioned impaired survival. ${ }^{15}$ Figure 1 shows the slightly lower survival of this selected cohort than that of the general

TABLE 3. Long-term outcome of several comparable studies

\begin{tabular}{|c|c|c|c|c|}
\hline Investigator & Prosthesis type & Patient age $(\mathbf{y})$ & Survival $(\%)$ & Freedom from reoperation $(\%)$ \\
\hline Present study & EPP & 53.1 & $\begin{array}{l}10 \text { y: } 71.8 \% \\
15 \text { y: } 48.8 \%\end{array}$ & $\begin{array}{l}10 \text { y: } 85.6 \% \\
14 \text { y: } 65.2 \% \\
\text { Median: } 14.5 \text { y }\end{array}$ \\
\hline Welke et al, ${ }^{19} 2011$ & Stented bioprosthesis (Carpentier-Edwards) & 50-64 (mean NR) & $\begin{array}{l}10 \mathrm{y}: \sim 72 \% \\
15 \mathrm{y}: \sim 57 \%\end{array}$ & $\begin{array}{l}10 \mathrm{y}: 68 \% \\
15 \mathrm{y}: \sim 41 \%\end{array}$ \\
\hline McClure et al, ${ }^{22} 2010$ & Stented bioprosthesis (Carpentier-Edwards) & $\leq 65$ y (mean NR) & $\begin{array}{l}10 \text { y: } 71.5 \% \\
15 \text { y: } 43.7 \%\end{array}$ & NR for age $\leq 65 y$ \\
\hline Valfre et $a,^{23} 2010$ & Hancock II stented bioprosthesis & $\leq 60$ y $($ mean NR) & $\begin{array}{l}10 \text { y: } 69.4 \% \\
15 \text { y: } 60.0 \%\end{array}$ & $\begin{array}{l}10 \text { y: } 87.4 \% \\
15 \text { y: } 62.6 \%\end{array}$ \\
\hline \multirow[t]{2}{*}{ Ruel et al, ${ }^{16} 2007$} & Stented bioprosthesis & $47.6 \mathrm{y}$ & $\begin{array}{l}10 \mathrm{y}: \sim 80.0 \% \\
15 \mathrm{y}: \sim 75.0 \% \\
20 \mathrm{y}: 65.5 \%\end{array}$ & $\begin{array}{l}20 \mathrm{y}: 11.4 \% \\
\text { Median: } 10.2 \mathrm{y}\end{array}$ \\
\hline & Mechanical prosthesis & $47.6 \mathrm{y}$ & $\begin{array}{l}10 \mathrm{y}: \sim 80.0 \% \\
15 \mathrm{y}: \sim 70.0 \% \\
20 \mathrm{y}: 52.3 \%\end{array}$ & $\begin{array}{l}20 \mathrm{y}: 73.0 \% \\
\text { Median: }>35 \mathrm{y}\end{array}$ \\
\hline Rizzoli et al, ${ }^{24} 2006$ & Hancock II stented bioprosthesis & $\leq 60 \mathrm{y}($ mean NR $)$ & NR for age $\leq 60 \mathrm{y}$ & $15 \mathrm{y}: 55.8 \%$ \\
\hline \multirow[t]{2}{*}{ Oxenham et al, ${ }^{18} 2003$} & Mechanical prosthesis (Bjork-Shiley) & $53.9 \mathrm{y}$ & $\begin{array}{l}10 \text { y: } 64.0 \% \\
20 \text { y: } 28.4 \%\end{array}$ & $\begin{array}{l}10 \text { y: } 95.8 \% \\
20 \text { y: } 92.6 \%\end{array}$ \\
\hline & Stented bioprosthesis & $53.9 \mathrm{y}$ & $\begin{array}{l}10 \text { y: } 65.7 \% \\
20 \text { y: } 31.1 \%\end{array}$ & $\begin{array}{l}10 \text { y: } 88.7 \% \\
20 \text { y: } 43.8 \%\end{array}$ \\
\hline \multirow[t]{2}{*}{$\begin{array}{l}\text { Hammermeister et al, } \\
\text { 2000, } 1993\end{array}$} & Mechanical prosthesis & $59 \mathrm{y}$ & $\begin{array}{l}11 \mathrm{y}: 47 \% \\
15 \mathrm{y}: 34 \%\end{array}$ & $\begin{array}{l}11 \text { y: } 93 \% \\
15 \text { y: } 90 \%\end{array}$ \\
\hline & Stented bioprosthesis & $59 \mathrm{y}$ & $\begin{array}{l}11 \text { y: } 41 \% \\
15 \text { y: } 21 \%\end{array}$ & $\begin{array}{l}11 \text { y: } 84 \% \\
15 \text { y: } 71 \%\end{array}$ \\
\hline Chambers et al, ${ }^{20} 1997$ & $\begin{array}{l}\text { Pulmonary autograft procedure (Ross } \\
\text { procedure) }\end{array}$ & $32 \mathrm{y}$ & 20 y: $61 \%$ & $\begin{array}{l}20 \text { y: autograft, } 75 \% \\
20 \text { y: homograft, } 80 \%\end{array}$ \\
\hline
\end{tabular}


population. If one remembers that the reported mortality rates for younger patients after AVR have been greater than those in the general population, but that older patients reach the same survival rate as the general population, ${ }^{19}$ these are satisfactory results.

In terms of the durability of bioprosthetic AVR, the freedom from reoperation rates in the different studies were comparable (Table 3). In summary, EPP showed better freedom from reoperation rates than did various other studied valves, especially remembering the low mean age of our study cohort with its effect on lowering durability. ${ }^{5}$ In the present study, age did not lower the freedom from reoperation (Table 2), another indication of the superior durability of EPP. Mechanical AVR showed superior durability; however, the low reoperation rates for mechanical AVR must be weighed against the disadvantages. The pulmonary autograft procedure shows high freedom from autograft or pulmonary position homograft replacement ${ }^{20}$ but is still controversial regarding late autograft competence and the consequences of creating pulmonary valve disease. Additionally, it was primarily used for patients far younger than those in our cohort and lacks comparable long-term results. ${ }^{20}$

In particular, patients with impaired left ventricular function should be considered. The improved hemodynamic behavior of SAVs has been reported to lead to an improvement in left ventricular function ${ }^{10}$ and a resulting survival benefit. ${ }^{21}$ In general, patients with impaired left ventricular function tend to have a worse outcome. This results in a reduction of patients in need of reoperation. Because of the high freedom from reoperation observed in the present study, the implantation of EPP can be especially recommended for these patients.

\section{Study Limitations}

The major limitation was the retrospective nature of our study, which could have led to an underestimation of the complication rates owing to patient misinterpretation or recall bias. Despite this limitation, we must remember that a controlled randomized trial of young patients involving stentless, stented, and mechanical AVR is not possible or, at least, would very difficult to perform.

\section{CONCLUSIONS}

After AVR with EPP in younger patients (which, to our knowledge, has not yet been studied in larger cohorts), we found long-term results in survival, comparable to those for stented biologic AVR and mechanical AVR. Freedom from reoperation after implantation of EPP was at least comparable to that after stented AVR but was worse than that after mechanical prostheses.

We have concluded that AVR with EPP is also an acceptable option for the treatment of aortic valve disease in younger patients.

\section{References}

1. Kunadian B, Vijayalakshmi K, Thornley AR, de Belder MA, Hunter S, Kendall S, et al. Meta-analysis of valve hemodynamics and left ventricular mass regression for stentless versus stented aortic valves. Ann Thorac Surg. 2007;84:73-8

2. Cunanan CM, Cabiling CM, Dinh TT, Shen SH, Tran-Hata P, Rutledge JH III, et al. Tissue characterization and calcification potential of commercial bioprosthetic heart valves. Ann Thorac Surg. 2001;71(5 Suppl):S417-21.

3. Jin XY, Ratnatunga C, Pillai R. Performance of Edwards Prima stentless aortic valve over eight years. Semin Thorac Cardiovasc Surg. 2001;13(4 Suppl 1): $163-7$.

4. Rahimtoola SH. Choice of prosthetic heart valve in adults: an update. J Am Coll Cardiol. 2010;55:2413-26.

5. Hammermeister K, Sethi GK, Henderson WG, Grover FL, Oprian C, Rahimtoola SH. Outcomes 15 years after valve replacement with a mechanical versus a bioprosthetic valve: final report of the Veterans Affairs randomized trial. J Am Coll Cardiol. 2000;36:1152-8.

6. Akins CW, Miller DC, Turina MI, Kouchoukos NT, Blackstone EH, Grunkemeier GL, et al. Guidelines for reporting mortality and morbidity after cardiac valve interventions. J Thorac Cardiovasc Surg. 2008;135:732-8.

7. Statistisches Bundesamt Wiesbaden, editor. Bevölkerung und Erwerbstätigkeit, Fachserie 1, Reihe 1, Gebiet und Bevölkerung 1993. Stuttgart: Statistisches Bundesamt Wiesbaden, Metzler-Poeschel Verlag; 1995:178-9.

8. Bonow RO, Carabello B, de Leon AC Jr, Edmunds LH Jr, Fedderly BJ, Freed MD, et al. ACC/AHA guidelines for the management of patients with valvular heart disease: a report of the American College of Cardiology/American Heart Association Task Force on Practice Guidelines (Committee on Management of Patients with Valvular Heart Disease). J Am Coll Cardiol. 1998;32: 1486-582.

9. Bonow RO, Carabello BA, Kanu C, de Leon AC Jr, Faxon DP, Freed MD, et al. ACC/AHA 2006 guidelines for the management of patients with valvular heart disease: a report of the American College of Cardiology/American Heart Association Task Force on Practice Guidelines (writing committee to revise the 1998 Guidelines for the Management of Patients With Valvular Heart Disease): developed in collaboration with the Society of Cardiovascular Anesthesiologists: endorsed by the Society for Cardiovascular Angiography and Interventions and the Society of Thoracic Surgeons. Circulation. 2006;114:e84-231.

10. Ali A, Halstead JC, Cafferty F, Sharples L, Rose F, Coulden R, et al. Are stentless valves superior to modern stented valves? A prospective randomized trial. Circulation. 2006;114(1 Suppl):I535-40.

11. Lehmann S, Walther T, Kempfert J, Leontjev S, Rastan A, Falk V, et al. Stentless versus conventional xenograft aortic valve replacement: midterm results of a prospectively randomized trial. Ann Thorac Surg. 2007;84:467-72.

12. Weber A, Noureddine H, Englberger L, Dick F, Gahl B, Aymard T, et al. Ten-year comparison of pericardial tissue valves versus mechanical prostheses for aortic valve replacement in patients younger than 60 years of age. J Thorac Cardiovasc Surg. 2012;144:1075-83.

13. Bach DS, Metras J, Doty JR, Yun KL, Dumesnil JG, Kon ND. Freedom from structural valve deterioration among patients aged $<$ or $=60$ years undergoing Freestyle stentless aortic valve replacement. J Heart Valve Dis. 2007;16: 649-55; discussion 656 .

14. Oosterlinck W, Meuris B, Herregods M-C, Vandeplas A, Daenen W, Flameng W, et al. Long-term results with a stentless porcine aortic valve: the Edwards PRIMA model 2500. J Heart Valve Dis. 2009;18:198-206.

15. Butchart EG, Li HH, Payne N, Buchan K, Grunkemeier GL. Twenty years' experience with the Medtronic Hall valve. J Thorac Cardiovasc Surg. 2001;121: 1090-100.

16. Ruel M, Chan V, Bédard P, Kulik A, Ressler L, Lam BK, et al. Very longterm survival implications of heart valve replacement with tissue versus mechanical prostheses in adults $<60$ years of age. Circulation. 2007;116(11 Suppl):I294-300.

17. Butchart EG, Gohlke-Bärwolf C, Antunes MJ, Tornos P, De Caterina R, Cormier B, et al. Recommendations for the management of patients after heart valve surgery. Eur Heart J. 2005;26:2463-71.

18. Oxenham H, Bloomfield P, Wheatley DJ, Lee RJ, Cunningham J, Prescott RJ, et al. Twenty year comparison of a Bjork-Shiley mechanical heart valve with porcine bioprostheses. Heart. 2003;89:715-21.

19. Welke KF, Wu Y, Grunkemeier GL, Ahmad A, Starr A. Long-term results after Carpentier-Edwards pericardial aortic valve implantation, with attention to the impact of age. Heart Surg Forum. 2011;14:E160-5. 
20. Chambers JC, Somerville J, Stone S, Ross DN. Pulmonary autograft procedure for aortic valve disease: long-term results of the pioneer series. Circulation. 1997;96:2206-14.

21. Gulbins H, Reichenspurner H. Which patients benefit from stentless aortic valve replacement? Ann Thorac Surg. 2009;88:2061-8.

22. McClure RS, Narayanasamy N, Wiegerinck E, Lipsitz S, Maloney A, Byrne JG, et al. Late outcomes for aortic valve replacement with the Carpentier-Edwards pericardial bioprosthesis: up to 17-year follow-up in 1,000 patients. Ann Thoracic Surg. 2010;89:1410-6.
23. Valfre C, Ius P, Minniti G, Salvador L, Bottio T, Cesari F, et al. The fate of Hancock II porcine valve recipients 25 years after implant. Eur J Cardiothorac Surg. 2010;38:141-6.

24. Rizzoli G, Mirone S, Ius P, Polesel E, Bottio T, Salvador L, et al. Fifteen-year results with the Hancock II valve: a multicenter experience. J Thorac Cardiovasc Surg. 2006;132:602-9.

25. Hammermeister KE, Sethi GK, Henderson WG, Oprian C, Kim T, Rahimtoola S. A comparison of outcomes in men 11 years after heart-valve replacement with a mechanical valve or bioprosthesis. N Engl J Med. 1993;328:1289-96. 